\title{
Production and partial characterization of extracellular amylase enzyme from Bacillus amyloliquefaciens P-001
}

\author{
Promita Deb ${ }^{1}$ Saimon Ahmad Talukdar' ${ }^{1}$ Kaniz Mohsina', Palash Kumar Sarker ${ }^{2}$ and SM Abu Sayem
}

\begin{abstract}
Amylases are one of the most important enzymes in present-day biotechnology. The present study was concerned with the production and partial characterization of extracellular amylase from Bacillus amyloliquefaciens P-001. The effect of various fermentation conditions on amylase production through shake-flask culture was investigated. Enzyme production was induced by a variety of starchy substrate but corn flour was found to be a suitable natural source for maximum production. Tryptone and ammonium nitrate (0.2\%) as nitrogen sources gave higher yield compared to other nitrogen sources. Maximum enzyme production was obtained after 48 hrs of incubation in a fermentation medium with initial $\mathrm{pH} 9.0$ at $42^{\circ} \mathrm{C}$ under continuous agitation at $150 \mathrm{rpm}$. The size of inoculum was also optimized which was found to be $1 \%(\mathrm{v} / \mathrm{v})$. Enzyme production was 2.43 times higher after optimizing the production conditions as compared to the basal media. Studies on crude amylase revealed that optimum $\mathrm{pH}$, temperature and reaction time of enzyme activity was $6.5,60^{\circ} \mathrm{C}$ and 40 minutes respectively. About $73 \%$ of the activity retained after heating the crude enzyme solution at $50^{\circ} \mathrm{C}$ for $30 \mathrm{~min}$. The enzyme was activated by $\mathrm{Ca}^{2+}$ (relative activity 146.25\%). It was strongly inhibited by $\mathrm{Mn}^{2+}, \mathrm{Zn}^{2+}$ and $\mathrm{Cu}^{2+}$, but less affected by $\mathrm{Mg}^{2+}$ and $\mathrm{Fe}^{2+}$.
\end{abstract}

Keywords: Bacillus amyloliquefaciens, Extracellular amylase, Shake flask culture, Production optimization, Characterization

\section{Background}

Microbial enzymes are widely used in industrial processes due to their low cost, large productivity, chemical stability, environmental protection, plasticity and vast availability (Burhan et al. 2003; Mishra \& Behera 2008). Bacillus species such as Bacillus subtilis, Bacillus amyloliquefaciens and Bacillus licheniformis are used as bacterial workhorses in industrial microbial cultivations for the production of a variety of enzymes as well as fine biochemicals for decades. A large quantity (20-25g/l) of extracellular enzymes has been produced and secreted by the various Bacillus strains which have placed them among the most significant industrial enzyme producers. The estimated value of world market is presently about US\$ 2.7 billion and is estimated to increase by $4 \%$ annually through 2012. Detergents (37\%), textiles (12\%),

\footnotetext{
* Correspondence: asayem08@yahoo.com

'Department of Genetic Engineering and Biotechnology, Shahjalal University of Science and Technology, Sylhet, Bangladesh

Full list of author information is available at the end of the article
}

starch (11\%), baking (8\%) and animal feed (6\%) are the main industries, which use about $75 \%$ of industrially produced enzymes (Harwood 1992; Ferrari et al. 1993; Schallmey et al. 2004; Das et al. 2011). Amylases are among the most important enzymes and are of great significance for biotechnology, constituting a class of industrial enzymes having approximately $25-30 \%$ of the world enzyme market (Azad et al. 2009; Rajagopalan \& Krishnan 2008). Initially the term amylase was used originally to designate an extracellular enzymes capable of hydrolyzing $\alpha-1,4$-glucosidic linkages in polysaccharides containing three or more 1,4- $\alpha$-linked glucose units. The enzyme acts on starches, glycogen and oligosaccharides in a random manner, liberating reducing groups. These enzymes are found in prokaryote as well as in eukaryotic organisms. They are widely distributed in microbial, plant and animal kingdoms. In the present day scenario, amylases have a great commercial value in biotechnological applications ranging from food, fermentation, textile to paper industries. These uses have placed 
greater stress on increasing amylase production and search for more efficient processes (Aehle \& Misset 1999; Lin \& Hsu 1997; Wolfgang 2007). For the maximum enzyme production, medium optimization is a prime step for its commercial usage.

The present work describes the effects of culture conditions on amylase production in batch experiments in shake flasks and under controlled conditions in a laboratory incubator. In this study, we show that enzyme synthesis is affected by carbon and nitrogen sources and maximal activity is attained with inorganic than organic nitrogen sources. The optimum enzyme production by the bacterial isolate was found at $42^{\circ} \mathrm{C}$, whereas maximum enzyme activity was observed at $60^{\circ} \mathrm{C}$. The enzyme was activated by $\mathrm{Ca}^{2+}$ (relative activity $146.25 \%$ ). It was strongly inhibited by $\mathrm{Mn}^{2+}, \mathrm{Zn}^{2+}$ and $\mathrm{Cu}^{2+}$, but less affected by $\mathrm{Mg}^{2+}$ and $\mathrm{Fe}^{2+}$.

\section{Results and Discussion}

The genus Bacillus produces a large variety of extracellular enzymes, of which amylases are of particularly considerable industrial importance (Swain et al. 2006). Present study deals with the production condition optimization and partial characterization of crude extracellular amylase produced by Bacillus amyloliquefaciens P-001. Bacillus amyloliquefaciens P-001 were able to hydrolyze starch showing zone of hydrolysis around the colonies on agar medium supplemented with soluble starch (Figure 1).

Therefore, further studies on enzyme production in shake-flask cultures were carried out using Bacillus amyloliquefaciens P-001. The organism was used for extracellular amylase production in shake-flask culture using basal medium $\left(0.1 \% \mathrm{KH}_{2} \mathrm{PO}_{4}, 0.25 \% \mathrm{Na}_{2} \mathrm{HPO}_{4}\right.$,

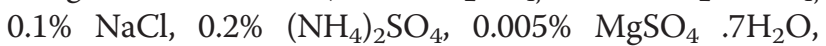
$0.005 \% \mathrm{CaCl}_{2}, 0.2 \%$ tryptone and $1 \%$ soluble starch, $\mathrm{pH}$ 6.5) (Bose \& Das 1996) for 48 hrs hours of incubation at $37^{\circ} \mathrm{C}$ and enzyme activity was obtained $35.0 \mathrm{U} / \mathrm{ml}$. To enhance the production of enzyme various parameters associated with the production of amylase were studied in the medium used for the enzyme production. Optimization of culture conditions is very important for maximum microbial growth and enzyme production by microorganisms (Kathiresan \& Manivannan 2006). Among the physical and chemical parameters, optimum temperature, $\mathrm{pH}$ range, carbon and nitrogen sources are the most important for enzyme production by microbes (Bose \& Das 1996; Gupta et al. 2003).

Among physical parameters, $\mathrm{pH}$ of the growth medium plays an important role in enzyme secretion. The $\mathrm{pH}$ range observed during the growth of microbes also affects product stability in the medium (Banargee \& Bhattacharya 1992). Most of the earlier studies revealed an optimum $\mathrm{pH}$ range between 6.0 and 7.0 for the growth of bacterial strains and enzyme production (Gupta et al. 2003; Kundu et al. 1973; Castro et al. 1992). Previous studies have revealed that fungi required slightly acidic $\mathrm{pH}$ and bacteria required neutral $\mathrm{pH}$ for optimum growth (Gangadharan et al. 2006). So, the effect of initial $\mathrm{pH}$ on the production of amylase by Bacillus amyloliquefaciens P-001 was investigated at different $\mathrm{pH}$ (6.0-9.5). The activity of the enzyme was

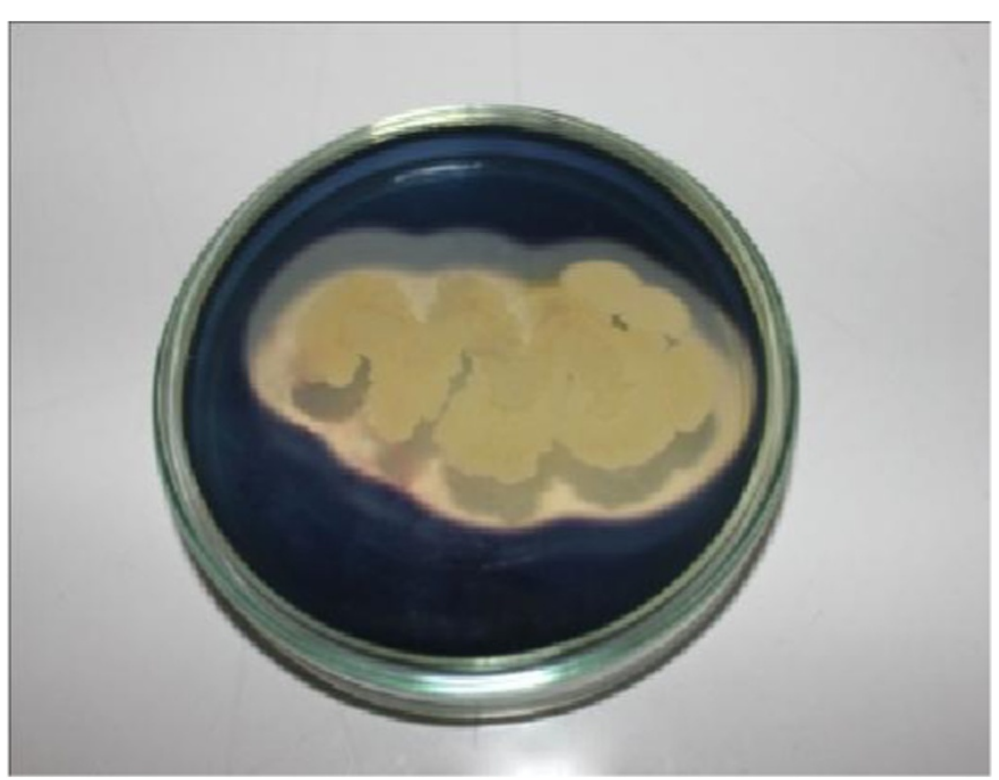

Figure 1 Zone of clearance due to the hydrolysis of starch. Screening of bacterial isolate for capability of amylase production was done by starch hydrolysis plate assay method. Bacterial isolate was streaked as a line on the starch agar plate and plates were incubated at $37^{\circ} \mathrm{C}$ for $24 \mathrm{~h} \& 48 \mathrm{~h}$. 
obtained at slightly alkaline $\mathrm{pH}$ 9.0. But, the final $\mathrm{pH}$ of the medium (initial $\mathrm{pH}$ 9.0) of shake flask fermentation was 7.5. At neutral $\mathrm{pH}$, the results were moderate and at acidic $\mathrm{pH}$ the enzyme activity was extremely low (Table 1). It might be due to the fact that the enzyme was inactive in the acidic medium (Castro et al. 1993). (Nusrat \& Rahman 2007) reported that, $\alpha$-amylase production at $\mathrm{pH} 7.0$ by the Bacillus amyloliquefaciens was maximum. Another study conducted by O. El-Tayeb (2007) showed that alpha amylase production by Bacillus amyloliquefaciens (strain $267 \mathrm{CH}$ ) in fermentor was highest at pH 6.0. (El-Tayeb et al. 2007).

Temperature is a vital environmental factor which controls the growth and production of metabolites by microorganisms and this is usually varied from one organism to another (Banargee \& Bhattacharya 1992;
Kumar \& Takagi 1999). Bacterial amylases are produced at a much wider range of temperature. Bacillus amyloliquefaciens, B.subtilis, B. licheniformis and B. stearothermophilus are among the most commonly used Bacillus sp. reported to produce $\alpha$-amylase at temperatures 37-60 $0^{\circ} \mathrm{C}$ (Mendu et al. 2005; Mielenz 1983; Syu \& Chen 1997; Mishra et al. 2005). A wide range of temperature $\left(35-80^{\circ} \mathrm{C}\right)$ has been reported for optimum growth and $\alpha$-amylase production in bacteria (Burhan et al. 2003; Castro et al. 1992; Prakash et al. 2009; Lin et al. 1998). In present study, for the determination of optimum temperature for enzyme production, the fermentation was carried out at different temperatures (32 to $45^{\circ} \mathrm{C}$ ). Enzyme production was gradually increased with increasing temperature and maximum enzyme production was observed at $42^{\circ} \mathrm{C}$ (Table 1 ). The

Table 1 Effect of culture conditions for extracellular amylase production from Bacillus amyloliquefaciens P-001 in shake-flask cultivations

\begin{tabular}{|c|c|c|c|}
\hline Culture condition & $\begin{array}{c}\text { Amylase activity }(\mathrm{U} / \mathrm{ml}) \\
\text { (Mean } \pm \mathrm{SE})\end{array}$ & $\begin{array}{c}\text { Relative } \\
\text { activity (\%) }\end{array}$ & $\begin{array}{l}\text { Total soluble protein } \\
(\mathrm{mg} / \mathrm{ml})(\text { Mean } \pm \mathrm{SE})\end{array}$ \\
\hline \multicolumn{4}{|l|}{ Initial pH } \\
\hline 6.0 & $17.25 \pm 0.53$ & 48.13 & $0.87 \pm 0.01$ \\
\hline 6.5 & $22.65 \pm 0.58$ & 63.20 & $1.45 \pm 0.03$ \\
\hline 7.0 & $27.71 \pm 0.45$ & 77.32 & $1.03 \pm 0.04$ \\
\hline 7.5 & $28.09 \pm 0.93$ & 78.38 & $2.76 \pm 0.03$ \\
\hline 8.0 & $28.92 \pm 0.10$ & 80.69 & $3.01 \pm 0.04$ \\
\hline 8.5 & $31.01 \pm 0.94$ & 86.52 & $2.69 \pm 0.02$ \\
\hline 9.0 & $35.84 \pm 0.17$ & 100.00 & $2.84 \pm 0.03$ \\
\hline 9.5 & $25.39 \pm 0.31$ & 70.84 & $2.73 \pm 0.02$ \\
\hline \multicolumn{4}{|c|}{ Incubation temperature $\left({ }^{\circ} \mathrm{C}\right)$} \\
\hline 32 & $25.75 \pm 0.53$ & 46.88 & $3.34 \pm 0.05$ \\
\hline 35 & $37.14 \pm 0.89$ & 67.61 & $2.35 \pm 0.06$ \\
\hline 37 & $39.20 \pm 0.19$ & 71.36 & $2.09 \pm 0.05$ \\
\hline 40 & $53.85 \pm 0.40$ & 98.03 & $1.79 \pm 0.02$ \\
\hline 42 & $54.93 \pm 0.18$ & 100.00 & $1.18 \pm 0.03$ \\
\hline 45 & $30.33 \pm 0.59$ & 55.22 & $2.40 \pm 0.04$ \\
\hline \multicolumn{4}{|l|}{ Incubation period (hr) } \\
\hline 24 & $10.49 \pm 0.19$ & 38.24 & $4.15 \pm 0.04$ \\
\hline 48 & $27.43 \pm 0.08$ & 100.00 & $3.97 \pm 0.07$ \\
\hline 72 & $26.28 \pm 0.21$ & 95.81 & $3.84 \pm 0.05$ \\
\hline 96 & $24.04 \pm 0.07$ & 87.64 & $3.23 \pm 0.06$ \\
\hline \multicolumn{4}{|c|}{ Inoculums volume (\%) } \\
\hline 1.0 & $39.25 \pm 0.20$ & 100.00 & - \\
\hline 1.5 & $35.92 \pm 0.27$ & 91.52 & - \\
\hline 2.0 & $34.46 \pm 0.17$ & 87.80 & - \\
\hline 2.5 & $31.18 \pm 0.27$ & 79.44 & - \\
\hline 3.0 & $30.97 \pm 0.18$ & 78.90 & - \\
\hline 3.5 & $28.38 \pm 0.18$ & 72.31 & - \\
\hline
\end{tabular}

Data represent as mean \pm standard error (SE) for three replicates. 
optimum range for enzyme production was $40-42^{\circ} \mathrm{C}$. Nusrat \& Rahman (2007) reported that, $\alpha$-amylase production was maximum at temperature $37^{\circ} \mathrm{C}$ by the Bacillus amyloliquefaciens. Haq et al. (2010) reported that, the better activity of $\alpha$-amylase in stirred fermentor with working volume of $4.5 \mathrm{~L}$ was at $37^{\circ} \mathrm{C}$ in $48 \mathrm{~h}$ by using randomly induced mutant strain of Bacillus amyloliquefaciens EMS-6.

From the time course study in shake culture, it was found that the rate of enzyme production was increased with the increase in the fermentation period and reached its maximum activity after 48 hour incubation (Table 1 ). The total protein content obtained was $3.97 \mathrm{mg} / \mathrm{ml}$ at that time. A prolonged incubation time beyond 48 hour did not increase the enzyme production. These findings are similar to the result reported by Haq et al. (2010). A similar result was also found by Asgher et al. (2007) studied on Bacillus subtilis, Kaur \& Vyas (2012) in case of Bacillus sp. DLB 9 and Riaz (et al. 2003) in case of Bacillus subtilis. It might be due to the accumulation of other by products in the medium Riaz et al. (2003). Efficient induction might not occur until the stationary phase has been reached and the available carbon source was reduced (Huang et al. 2003; Wanderley et al. 2004). But, Abate et al. (1999) reported that the production of $\alpha$-amylase by Bacillus amyloliquefaciens starts at the beginning of the exponential growth phase reaching the maximum level after 24 hour and after that, $\alpha$-amylase level decreased drastically probably due to the accumulation of high level of protease activities concomitant with the sporulation process at the end of the exponential growth phase. Similar findings have been reported on Bacillus amyloliquefaciens Hillier et al. (1997) and Bacillus sp. ANT-6 Burhan et al. (2003).

The volume of inoculum plays an important role in the fermentation of enzymes Lin et al. (1998). In our study, $1 \%$ inoculum induced the maximum amylase production (Table 1). As the inoculum level was further increased, the production of enzyme was gradually decreased. It may be due to the fact that at high concentration of inoculum level, the bacteria grow rapidly and the nutrients present in the media were insufficient to overcome the growth of bacteria. Thus, the production of amylase was affected at higher concentration of inoculum. Our findings are in a good agreement with Riaz et al. (2003).

Natural sources could serve as economical and readily available raw material for the production of valuable enzymes. Agricultural wastes are being used for liquid fermentation to reduce the cost of fermentation media. These wastes consist of different carbon sources are necessary for the growth of microorganisms (Haq et al. 2005; Swamy \& Seenayya 1996; Djekrif-Dakhmouche et al. 2005). The nature and amount of carbon sources in culture media are important factor for the production of extracellular amylase Akcan (2011). It was found that $\alpha$-amylase production was maximum when starch was used as the carbon source (Gupta et al. 2003; Sumrin et al. 2011; Bandyopadhyay et al. 1993; Lin et al. 1994; Narang \& Satyanarayana 2001; Bozic et al. 2011; Sexana et al. 2007). Biosynthesis of the enzyme took place not only in the presence of starch but also with other carbon sources. Our study showed that the production of enzyme was highest when corn flour was used as carbon source in the basal media (Figure 2). Besides, rice flour and wheat bran showed moderate effects on enzyme synthesis. Earlier studies reported that, complex substrates induce higher amylase production Sexana et al. (2007).

The nature and relative concentration of different complex nitrogenous sources in the growth medium are both important in the synthesis of amylase. Lower levels of nitrogen and also excess nitrogen are equally detrimental causing enzyme inhibition Sharma et al. (2012). The influence of organic nitrogen sources on amylase production was determined. Among the different organic nitrogen sources tested, tryptone $(0.2 \%)$ was found to be a good nitrogen source for amylase production from Bacillus amyloliquefaciens P-001 (Figure 3). In fact, tryptone has been reported to be the best nitrogen source for amylase production Okalo et al. (1996). In present study, yeast extract, casein and beef extract also showed stimulating effects on amylase synthesis. It has been reported that yeast extract also served as good organic nitrogen source for $\alpha$-amylase synthesis from Bacillus amyloliquefaciens (Sharma et al. 2012; Magee \& Kosaric 1987). Similarly, casein was reported to be a good nitrogen source for $\alpha$-amylase production from $B$. subtilis IP 5832 Bozic et al. (2011). It was observed that inorganic nitrogen sources gave comparatively higher yields than organic nitrogen sources. In present study, the enzyme production was increased when ammonium nitrate used as inorganic nitrogen source in the culture media. According to Coleman \& Elliott (1962) ammonium salts were stimulators of B. subtilis amylase synthesis. Our findings are in a good agreement with the findings of these studies (Figure 4). It has also been reported that, ammonium nitrate and sodium nitrate were the best nitrogen sources for maximum amylase production (Kundu et al. 1973; Mahmood \& Rahman 2008). Ammonium chloride, ammonium sulphate showed stimulating effects on amylase production. It has been found that $\alpha$-amylase production by $B$. subtilis DM-03 was maximum when ammonium chloride as the nitrogen source Das et al. (2004). Swain et al. (2006) studied on Bacillus subtilis reporting that, urea inhibited $\alpha$-amylase activity which is similar to our findings.

A pH range from 5.5-8.0 was used to study the effect of $\mathrm{pH}$ on amylase activity (Figure 5) and optimum $\mathrm{pH}$ was found at 6.5 . In the alkaline $\mathrm{pH}$ range, the activity 


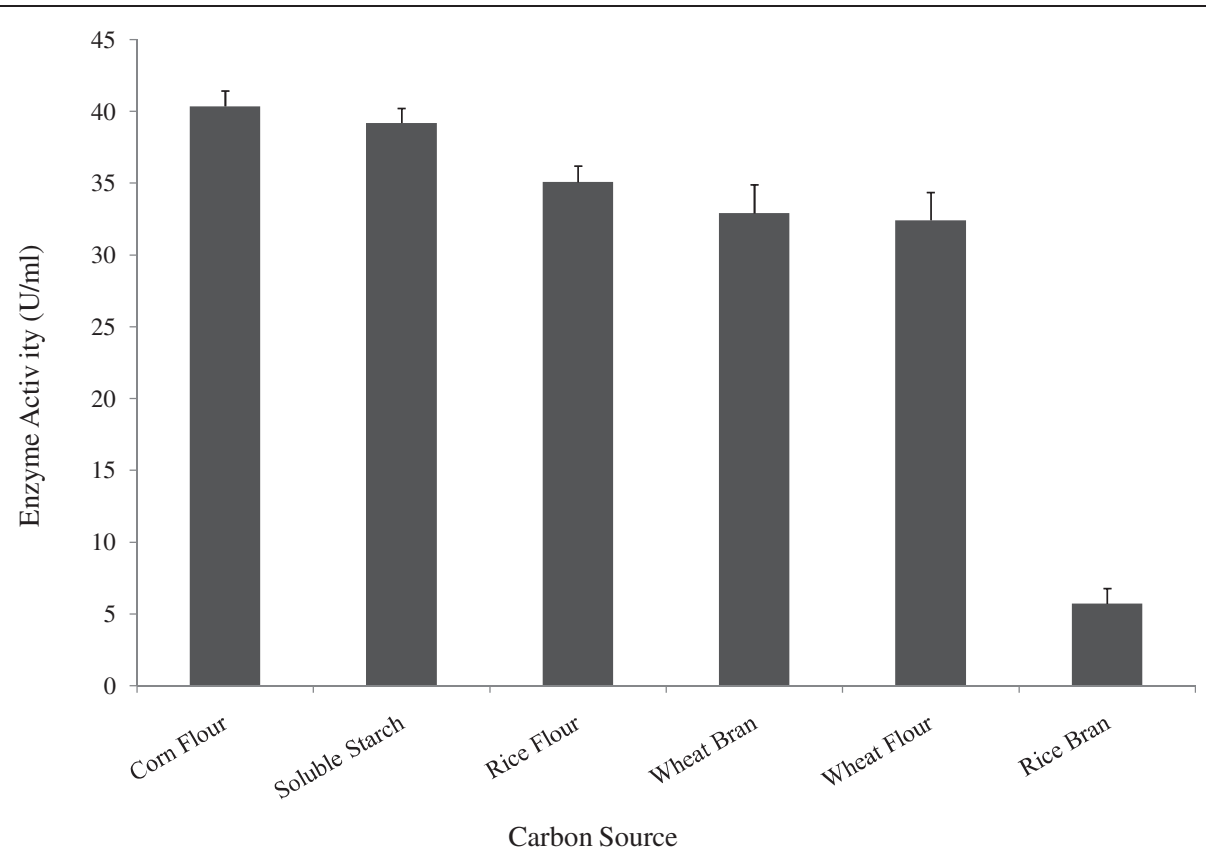

Figure 2 Effect of carbon sources on amylase production by Bacillus amyloliquefaciens P-001. The effect of different carbon sources on enzyme production was investigated by using $1 \%$ inoculums (w/ $/ \mathrm{V}$ in $100 \mathrm{ml}$ basal medium. The fermentation was carried out at $37^{\circ} \mathrm{C}$ at $150 \mathrm{rpm}$ for $48 \mathrm{hrs}$. Absorbance was measured at $540 \mathrm{~nm}$ with spectrophotometer and Enzyme activity was presented on the $y$ axis and carbon sources was on $\mathrm{x}$ axis. Bars represent means \pm standard deviations for three replicates.

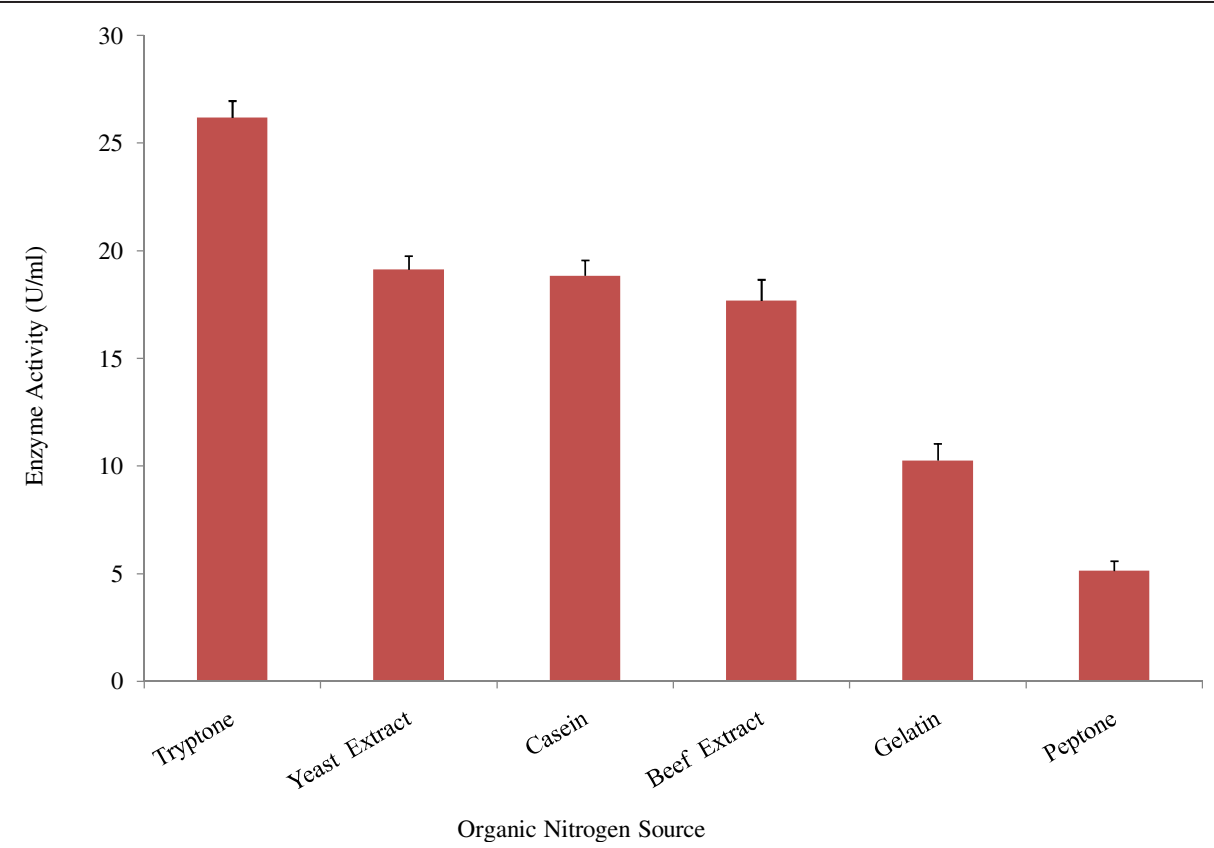

Figure 3 Effect of organic nitrogen source on amylase production by Bacillus amyloliquefaciens P-001. Different organic nitrogen sources $(0.2 \% \mathrm{~W} / \mathrm{v})$ in $100 \mathrm{ml}$ of basal medium were used for the experiment and the medium was incubated at $37^{\circ} \mathrm{C}$ at $150 \mathrm{rpm}$ for $48 \mathrm{~h}$ in a rotary shaking incubator. Enzyme activity was presented on the $y$ axis and organic nitrogen sources was on $x$ axis. Bars represent means \pm standard deviations for three replicates. 


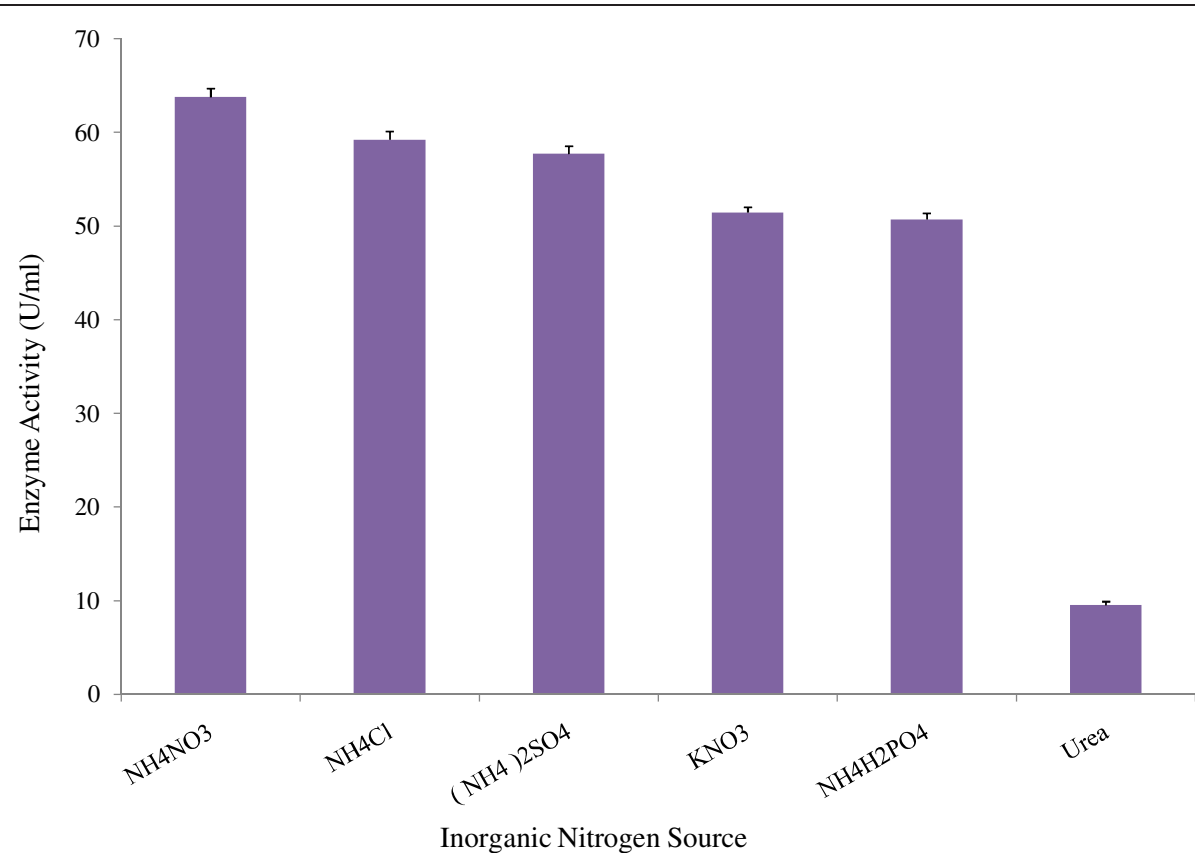

Figure 4 Effect of inorganic nitrogen source on amylase production by Bacillus amyloliquefaciens P-001. To determine the effect of inorganic nitrogen sources on enzyme production different inorganic nitrogen sources were used $(0.2 \% \mathrm{~W} / \mathrm{v})$ in $100 \mathrm{ml}$ of basal medium. The fermentation was carried out at $37^{\circ} \mathrm{C}$ at $150 \mathrm{rpm}$ for $48 \mathrm{~h}$. Bars represent means \pm standard deviations for three replicates.

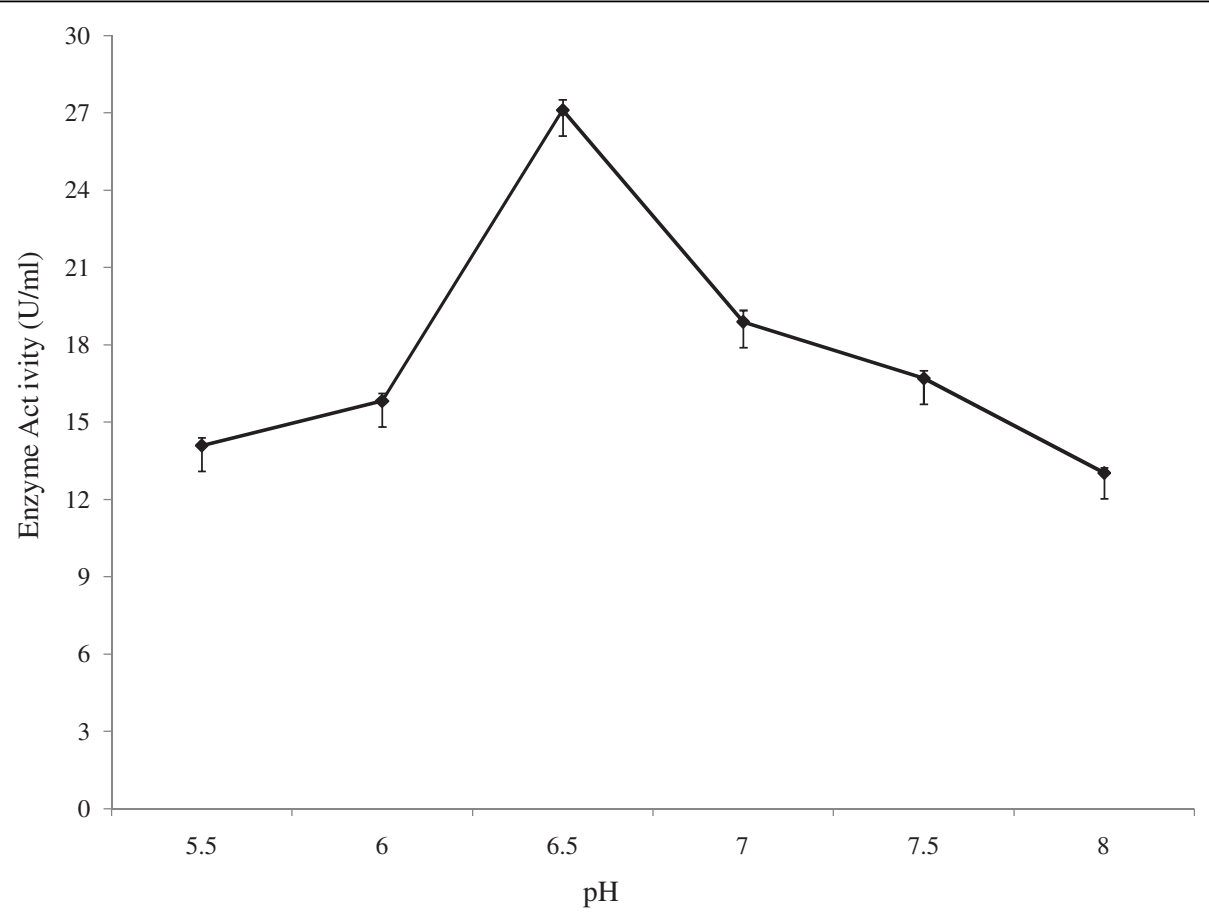

Figure 5 Effect of $\mathbf{p H}$ on enzyme activity. For determination of optimum assay pH of the enzyme reaction, $0.05 \mathrm{M} \mathrm{Na}_{2} \mathrm{HPO}_{4}-\mathrm{NaH}_{2} \mathrm{PO}_{4}$ buffer was used. The reaction was carried out for $10 \mathrm{~min}$ at $50^{\circ} \mathrm{C}$ in a shaking water. The enzyme activity was measured and the results are presented on graph. Bars represent means \pm standard deviations for three replicates. 
was lower. The effect of temperature on enzyme activity was assayed at different temperatures ranging from $35-70^{\circ} \mathrm{C}$ at optimum $\mathrm{pH}$. The results showed that enzyme activity was increased with temperature and it showed highest activity at temperature $60^{\circ} \mathrm{C}$ (Figure 6). Above $60^{\circ} \mathrm{C}$ temperature activity was also decreased. For determination of optimum reaction time, enzyme assay was carried out at different reaction time ranging from 5-50 minutes at constant temperature and $\mathrm{pH}$. It was observed (Figure 7) that, the enzyme exhibited its maximum activity at $40 \mathrm{~min}$ of reaction time. Aygan et al. (2008) in 2008 reported that enzyme obtained from Bacillus sp. AB68 was active in a broad temperature range between 20 and $90^{\circ} \mathrm{C}$, with an optimum of $50^{\circ} \mathrm{C}$. Stability of the enzyme is of great importance for the economy of their industrial application. In case of thermostabilty, the enzyme was pre incubated at different temperatures for $30 \mathrm{~min}$ and then enzyme was assayed. The results (Figure 8) showed that the enzyme activity was retained $73 \%$ after heating at $50^{\circ} \mathrm{C}$ for $30 \mathrm{~min}$. After this time the activity was decreased drastically and enzyme was completely inactivated when heated at $80^{\circ} \mathrm{C}$. Thus, the results concluded that the crude enzyme is moderately temperature stable. It is therefore worthwhile to consider means to stabilize the enzyme under storage conditions. Temperature is an important limiting factor for storage of enzymes. In our study, enzyme was stored at room temperature for 21 days. But, the room temperature was moderately suitable for the storage of this enzyme in considering commercialization and industrial application, thus causing the rapid reduction of enzyme activity. Only $66 \%$ of the activity retained at room temperature after 21 days (Figure 9).

Most of amylases are known to be metal ion-dependent enzymes, namely divalent ions like $\mathrm{Ca}^{2+}, \mathrm{Mg}^{2+}, \mathrm{Mn}^{2+}, \mathrm{Zn}^{2+}$, $\mathrm{Fe}^{2+}$ etc. Pandey et al. (2000). The effect of metal ions on amylase activity was measured in the presence of various metal ions at a concentration of $2 \mathrm{mM}$. Activities of enzyme were stimulated in the presence of $\mathrm{Ca}^{2+}, \mathrm{Mg}^{2+}$ and $\mathrm{Fe}^{2+}$ ions (Figure 10). On the other hand, a strong inhibitory effect was observed in the presence of $\mathrm{Cu}^{2+}, \mathrm{Zn}^{2+}$ and $\mathrm{Mn}^{2+}$. Results suggest that amylase did not require any metal ions for catalytic activity except $\mathrm{Ca}^{2+}$ and was activated (relative activity 146\%) by calcium. Tonkova (1991) and Chung et al. (1995) stated that, addition of $\mathrm{Ca}^{2+}$ ion is often significant for production and stability of amylase of many Bacillus spp. According to Gupta et al. (2003), $\alpha$-amylase contain at least one $\mathrm{Ca}^{2+}$ ion and affinity of $\mathrm{Ca}$ is much stronger than that of other metal ions.

\section{Conclusions}

The cultural conditions and composition of media for optimal production of amylase by $B$. amyloliquefaciens P-001 has been developed in this study. Enzyme synthesis was affected by carbon and nitrogen sources and maximal activity was attained with inorganic than organic nitrogen sources. The optimum enzyme production by the bacterial isolate was found at $42^{\circ} \mathrm{C}$, whereas maximum enzyme activity was observed at $60^{\circ} \mathrm{C}$ which

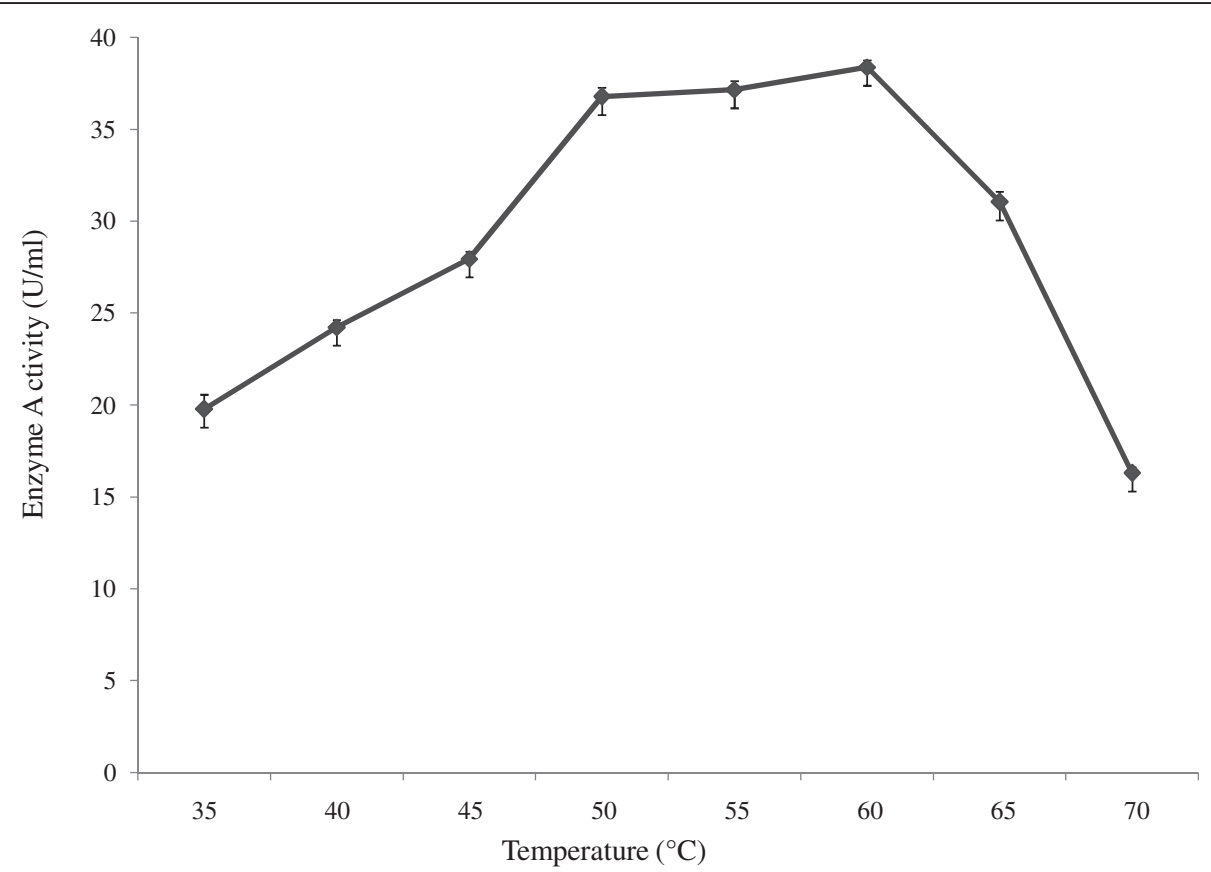

Figure 6 Effect of temperature on enzyme activity. To study the effect of temperature on enzyme reaction activity, the enzyme reaction was carried out at different temperatures for $10 \mathrm{~min}$ in a shaking water bath and results are presented on graph. Bars represent means \pm standard deviations for three replicates. 


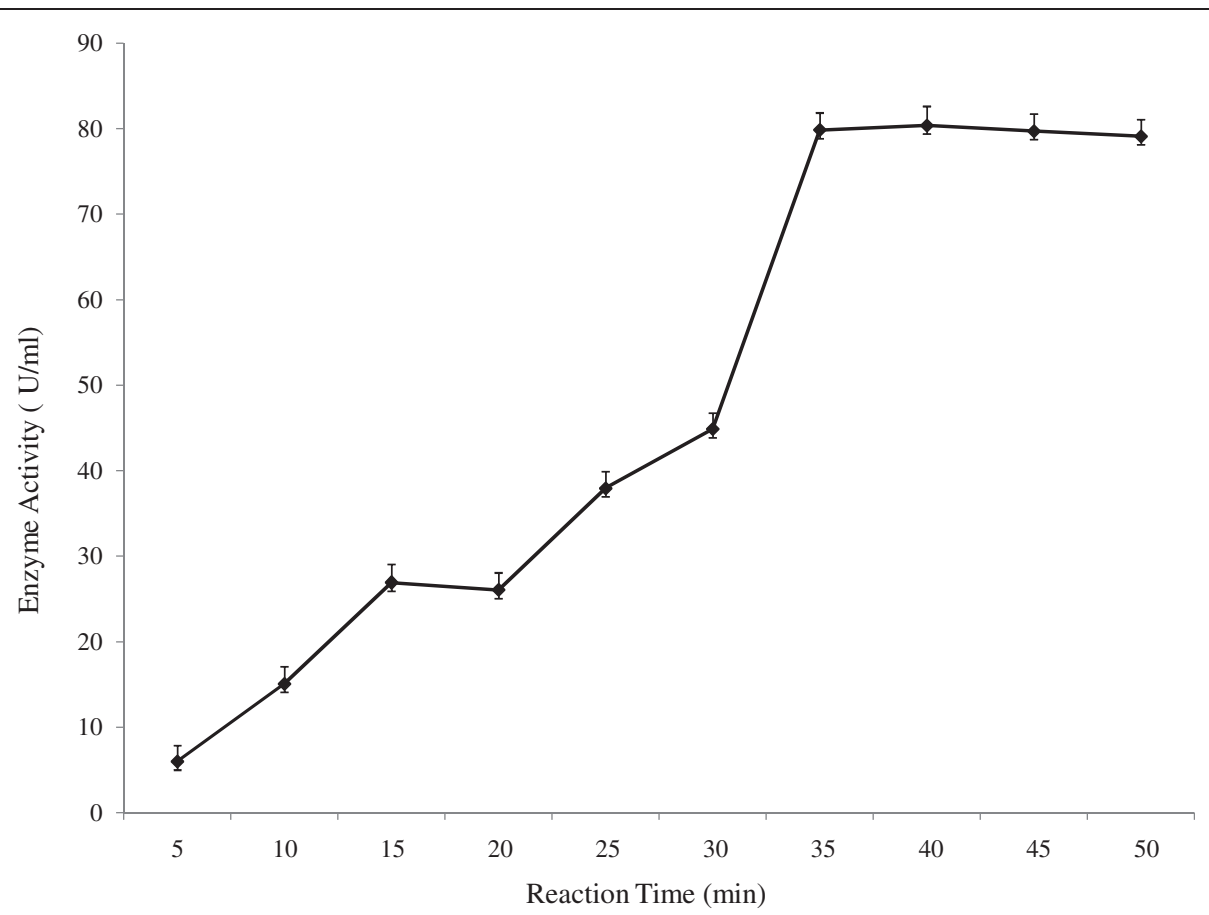

Figure 7 Effect of reaction time on enzyme activity. To investigate the optimum reaction period of the enzyme solution, reaction was carried out using $0.05 \mathrm{M}$ sodium phosphate buffer $(\mathrm{pH} 6.5)$ at $50^{\circ} \mathrm{C}$ in a water bath at different time intervals and the enzyme activity was then measured. The results are presented on graph. Bars represent means \pm standard deviations for three replicates.

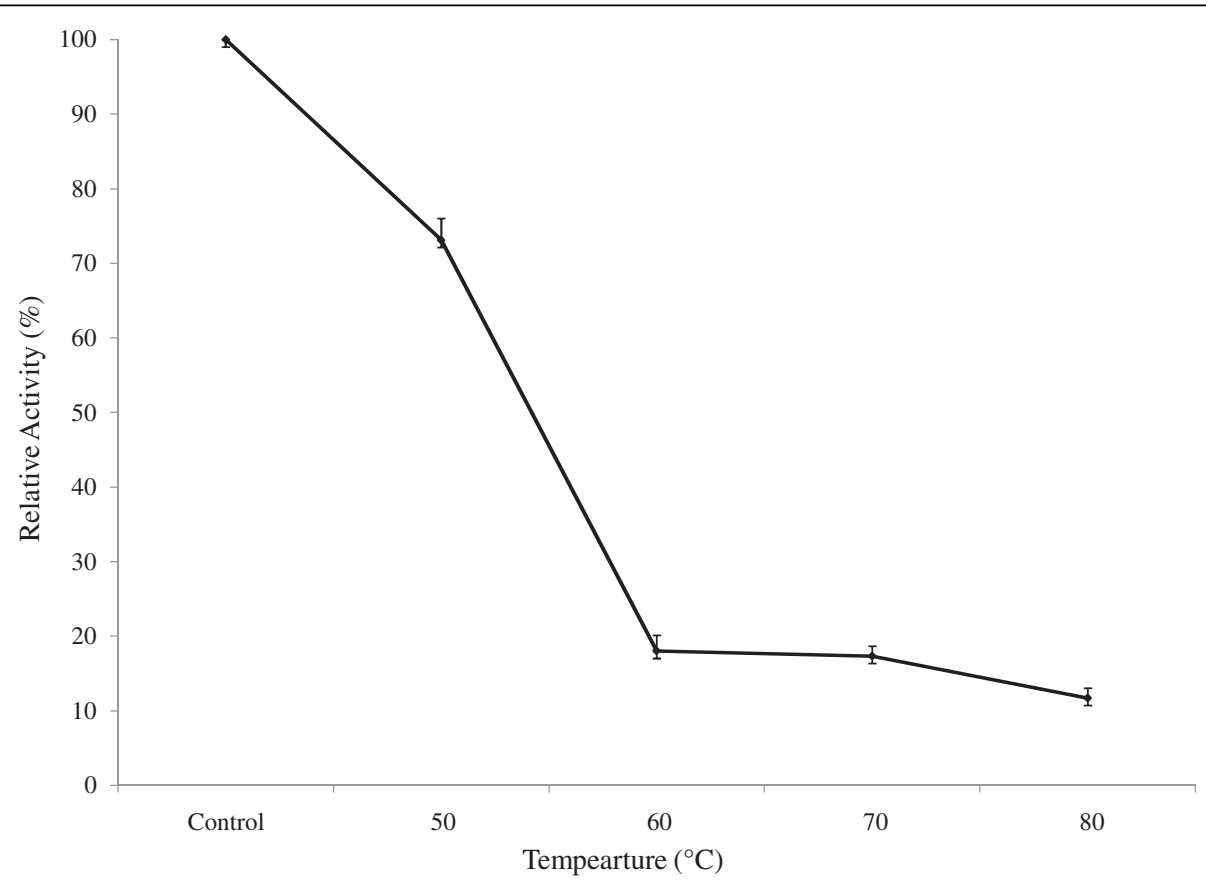

Figure 8 Thermal stability of enzyme. For the determination of thermostability of amylase, $1 \mathrm{ml}$ of sodium phosphate buffer ( $\mathrm{pH}$ 6.5) and $1 \mathrm{ml}$ of enzyme solution containing test tubes were heated at different temperatures for 30 minutes in a shaking water bath. Then enzyme activity of the heat treated enzymes was then measured and the results are presented on graph. Bars represent means \pm standard deviations for three replicates. 


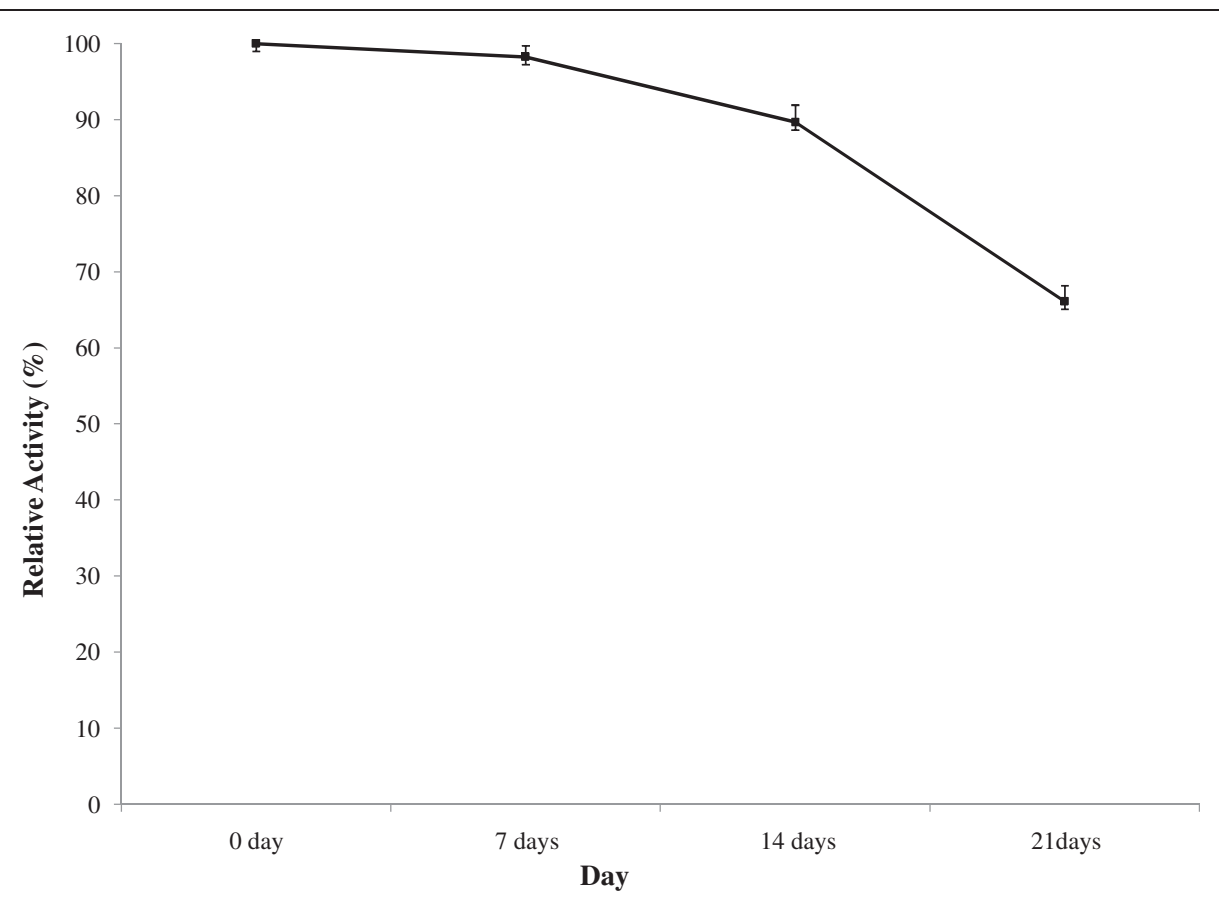

Figure 9 Storage stability of enzyme. To determine the storage stability of amylase enzyme, crude enzyme solution was stored at room temperature and the activity was measured at 7 days interval over a month by standard assay method described previously. The results are presented on graph. Bars represent means \pm standard deviations for three replicates.

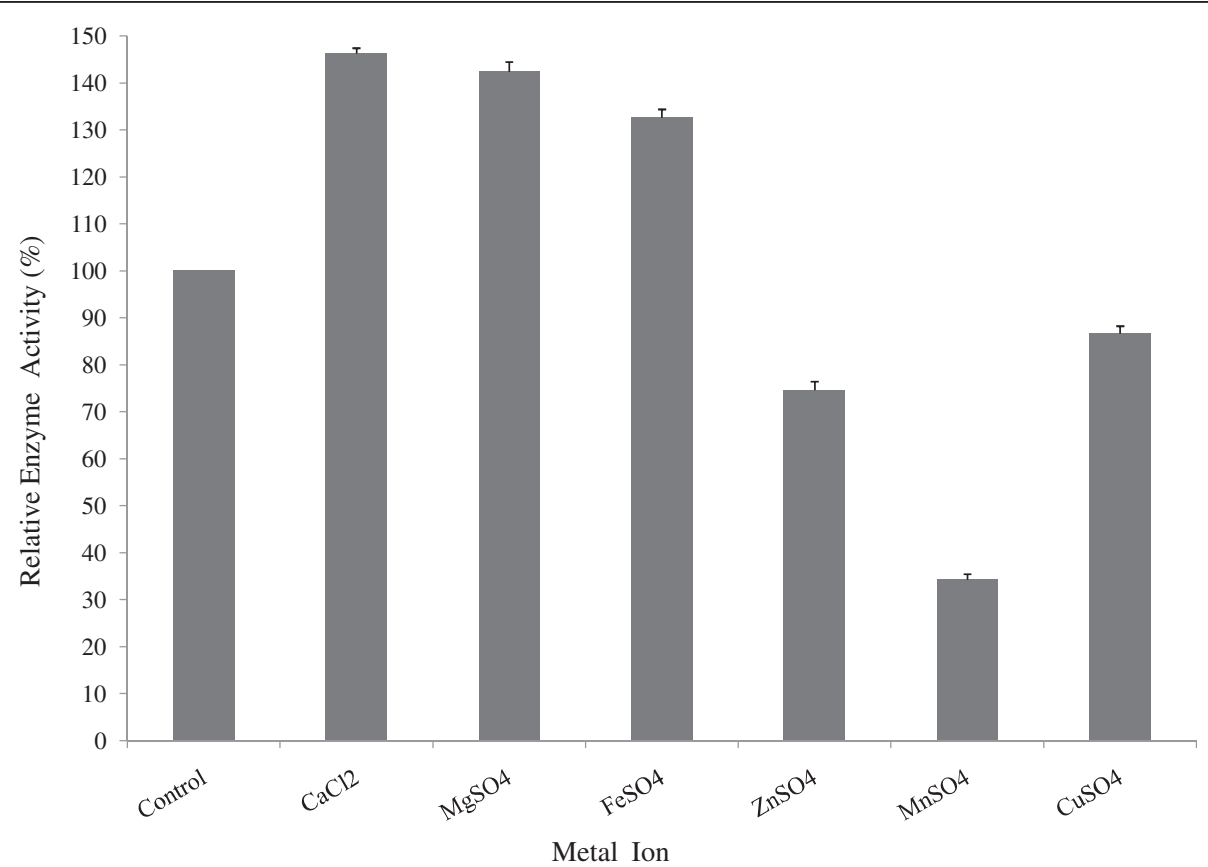

Figure 10 Effect of metal ions on enzyme activity. For determining the effect of metal ions on amylase activity, enzyme assay was performed after pre-incubation of the enzyme with various metal ions each at a concentration of $2 \mathrm{mM}$ at $50^{\circ} \mathrm{C}$ for $30 \mathrm{~min}$. The results are presented on graph. Bars represent means \pm standard deviations for three replicates. 
could make the enzyme from $B$. amyloliquefaciens P-001 more suitable for future use in various industries. It can be concluded that, B. amyloliquefaciens P-001 can be a potential producer of extracellular amylase which could find applications in industry. Due to the importance of these findings, further studies need be carried on in order to commercialize the production process.

\section{Methods}

\section{Microorganism}

The bacterial culture Bacillus amyloliquefacience P-001 was obtained from the Microbial Biotechnology Division, National Institute of Biotechnology, Ganakbari, Savar, Dhaka. It was maintained on nutrient agar medium. The organism was maintained at $4^{\circ} \mathrm{C}$ in refrigerator for routine laboratory use. For the long term preservation, the log phage growth bacteria were maintained in 15\% glycerol broth at $-20^{\circ} \mathrm{C}$.

\section{Plate assay method}

The Bacillus isolates were tested for amylase activity by employing zone clearing technique Atlas et al. (1995) using starch agar medium. The inoculated plates were incubated at $37^{\circ} \mathrm{C}$ for two days. After incubation, the zone of hydrolysis of starch was detected by flooding the plates with iodine solution. The development of blue colour indicated the presence of starch, while the areas around the hydrolytic bacteria appeared clear.

\section{Preparation of seed culture}

Vegetative inoculums were used in the present studies. Fifty millilitre of inoculums medium containing nutrient broth $13 \mathrm{~g} / \mathrm{l}, \mathrm{pH} 7.4 \pm 0.2$ was transferred to a $100 \mathrm{ml}$ conical flask and cotton plugged. It was sterilized in an autoclave at $15 \mathrm{lbs} / \mathrm{inch}^{2}$ pressure at $121^{\circ} \mathrm{C}$ for $20 \mathrm{~min}$. After cooling to room temperature, a loopful of freshly grown culture was aseptically transferred to it. The flask was incubated overnight at $37^{\circ} \mathrm{C}$ and $150 \mathrm{rpm}$ in a rotary shaking incubator.

\section{Enzyme production in shake flask cultures}

The enzyme production was carried out in the basal Asgher et al. (2007) medium containing $0.1 \% \mathrm{KH}_{2} \mathrm{PO}_{4}$, $0.25 \% \mathrm{Na}_{2} \mathrm{HPO}_{4}, 0.1 \% \mathrm{NaCl}, 0.2 \%\left(\mathrm{NH}_{4}\right)_{2} \mathrm{SO}_{4}, 0.005 \%$ $\mathrm{MgSO}_{4} .7 \mathrm{H}_{2} \mathrm{O}, 0.005 \% \mathrm{CaCl}_{2}, 0.2 \%$ tryptone and $1 \%$ soluble starch. $1 \mathrm{ml}$ of 24 hours grown inoculums were cultivated in 250-ml Erlenmeyer flasks containing $100 \mathrm{ml}$ of medium with an initial $\mathrm{pH}$ 7.0. The cultures were shaken at $150 \mathrm{rpm}$ in a orbital shaker incubator at $37^{\circ} \mathrm{C}$ for at least $48 \mathrm{~h}$ unless otherwise stated. After the incubation, the fermented broth was centrifuged in a refrigerated centrifuge machine at $8000 \mathrm{rpm}$ for 15 minutes at $4^{\circ} \mathrm{C}$.

\section{Enzyme assay}

Amylase was determined by using soluble starch, 1\% $(\mathrm{w} / \mathrm{v})$, as substrate in $0.05 \mathrm{M}$ Sodium phosphate buffer (pH 6.5) essentially according to Gomes et al. (2001). The reaction mixture containing $1.8 \mathrm{ml}$ substrate solution and $0.2 \mathrm{ml}$ suitably diluted enzyme solution was incubated at $50^{\circ} \mathrm{C}$ for $10 \mathrm{~min}$. The reaction was stopped by adding $3 \mathrm{ml}$ dinitrosalicylic acid (DNS). The reducing sugar released was determined by the method of Miller (1959). The absorbance was measured at $540 \mathrm{~nm}$ with spectrophotometer (Jenway 6305, USA). One unit (U) of enzyme activity is defined in all cases as the amount of enzyme releasing $1 \mu \mathrm{g}$ of reducing sugar as maltose per minute, under assay conditions.

\section{Soluble protein estimation}

Extracellular soluble protein in culture filtrate was estimated by the Lowry's method using bovine serum albumin (BSA) used as Standard Lowry et al. (1951). $2 \mathrm{ml}$ of analytical reagent was added to $0.2 \mathrm{ml}$ suitably diluted test samples (enzyme solution). The mixture was mixed well and allowed to stand for $10 \mathrm{~min}$ at $50^{\circ} \mathrm{C}$. Then $0.2 \mathrm{ml}$ of the folin-ciocalteau reagent was added and shaken to mix well and incubated at room temperature for about $30 \mathrm{~min}$. Optical density of the reaction mixture was measured at $600 \mathrm{~nm}$, against a blank prepared with $0.2 \mathrm{ml}$ buffer. A standard curve was constructed with each experiment using bovine serum albumin as a known protein. The amount of the soluble protein was calculated from the standard curve of as $\mathrm{mg}$ protein per $\mathrm{ml}$ of test samples.

\section{Competing interests}

The authors declare that they have no competing interests.

\section{Authors' contributions}

PKS planned the work that led to the manuscript; PD produced and analyzed the experimental data; SA and KM participated in the interpretation of the results; PD, KM, SMAS and PKS wrote the paper. All authors read and approved the final manuscript.

\section{Acknowledgements}

The research was supported by National Institute of Biotechnology, Savar, Dhaka, Bangladesh.

\section{Author details}

'Department of Genetic Engineering and Biotechnology, Shahjalal University of Science and Technology, Sylhet, Bangladesh. ${ }^{2}$ Microbial Biotechnology Division, National Institute of Biotechnology, Savar, Dhaka, Bangladesh.

Received: 12 February 2013 Accepted: 4 April 2013 Published: 10 April 2013

\section{References}

Abate CM, Castro NGR, Sineriz F, Callieri DAS (1999) Production of amylolytic enzymes by Bacillus amyloliquefaciens in pure culture and in co-culture with Zymomonas mobilis. Biotechnol Lett 21:249-252

Aehle W, Misset O (1999) Enzymes for industrial applications. In: Rehm HJ, Reed G (ed) Biotechnology, 2nd edition. Wiley-VCH, Germany

Akcan N (2011) High level production of extracellular a-amylase from Bacillus licheniformis ATCC 12759 in submerged fermentation. Rom Biotechnol Lett 16(6):6833-6840 
Asgher M, Asad MJ, Rahman SU, Legge RL (2007) A thermostable a-amylase from a moderately thermophilic Bacillus subtilis strain for starch processing. J Food Eng 79:950-955

Atlas RM, Parks LC, Brown AE (1995) Laboratory Manual of Experimental Microbiology. Mosby-Year Book Inc., St Louis

Aygan A, Arikan B, Korkmaz H, Dincer S, Colak O (2008) Highly thermostable and alkaline alpha amylase from halotolerant-alkaliphilic Bacillus sp. AB68. Braz J Microbiol 39:547-553

Azad MA, Bae JH, Kim JS, Lim JK, Song KS, Shin BS, Kim HR (2009) Isolation and characterization of a novel thermostable alpha-amylase from Korean pine seeds. N Biotechnol 26:143-149

Banargee R, Bhattacharya BC (1992) Extracellular alkaline protease of newly isolated Rhizopus oryzae. Biotechnol lett 14:301-304

Bandyopadhyay A, Pal SC, Sen SK (1993) Alpha amylase production in lactose medium by Bacillus circulanse ACB. Microbiologia 9(2):142-148

Bose K, Das D (1996) Thermostable a-amylase production using B. licheniformis NRRL B1438. Indian J Exp Biol 34:1279-1282

Bozic N, Ruiz J, Lopez-Santin J, Vujcic Z (2011) Optimization of the growth and a-amylase production of Bacillus subtilis IP 5832 in shake flask and laboratory fermenter batch cultures. J Serb Chem Soc 76(7):965-972

Burhan A, Nisa U, Gokhan C, Omer C, Ashabil A, Osman G (2003) Enzymatic properties of a novel thermophilic, alkaline and chelator resistant amylase from an alkalophilic Bacillus sp. Isolate ANT-6. Process Biochem 38:1397-1403

Castro PML, Hayter PM, Ison AP, Bull AT (1992) Application of statistical design to the optimization of culture mediumfor recombinant interferon-gamma production by Chinese hamsterovary cells. Appl Microbiol Biotechnol 38(1):84-90

Castro GR, Ferrero MA, Mendez BS, Sineriz F (1993) Screening and selection of bacteria with high amylolytic activity. Acta Biotechnol 13:197-201

Chung YC, Kobayashi T, Kanai H, Akiba T, Kudo T (1995) Purification and properties of extracellular amylase from the hyperthermophilic Archaeon Thermococcus profundus DT 5432. Appl Environ Microbiol 61(4):1502-1506

Coleman G, Elliott WH (1962) Studies on a-amylase formation by Bacillus subtilis. Biochem J 83(2):256-263

Das K, Doley R, Mukherjee AK (2004) Purification and biochemical characterization of thermostable, alkaliphilic, extracellular a-amylase from Bacillus subtilis DM-03, a strain isolated from the traditional food of India. Biotechnol Appl Biochem 40:291-298

Das S, Singh S, Sharma V, Soni ML (2011) Biotechnological applications of industrially important amylase enzyme. Inter J Phar Bio Sci 2(1):486-496

Djekrif-Dakhmouche S, Gheribi-Aoulmi Z, Meraihi Z, Bennamoun L (2005) Application of a statistical design to the optimization of culture medium for a-amylase production by Aspergillus niger ATCC 16404 grown on orange waste powder. J Food Eng 73:190-197

El-Tayeb O, Mohammed F, Hashem A, Abdullah M (2007) Optimization of the industrial production of bacterial alpha amyalse in Egypt. IV. Fermentor production and characterization of the enzyme of two strains of Bacillus subtilis and Bacillus amyloliquefaciens. Afr J Biotechnol 7(24):4521-4536

Ferrari E, Jarnagin AS, Schmidt BF (1993) Commercial Production of Extracellular Enzymes. In: Sonenheim AL, Hoch JA, Losick R (ed) Bacillus subtilis and Other Gram-Positive Bacteria: Biochemistry, Physiology, and Molecular Genetics. American Society for Microbiology Press, Washington DC

Gangadharan D, Sivaramakrishnan S, Namboothiri KM, Pandey A (2006) Solid culturing of Bacillus amyloliquefaciens for -amylase production. Food Technol Biotechnol 44(2):269-274

Gomes I, Sultana M, Uddin K, Gomes J, Steiner W, Gomes DJ (2001) Nutrient composition and fermentation conditions for a-amylase production by Bacillus amyloliquefaciens. Bangladesh J Microbiol 18(2):141-150

Gupta R, Gigras P, Mohapatra H, Goswami VK, Chauhan B (2003) Microbial a-amylases: a biotechnological prospective. Process Biochem 38:1599-1616

Haq I, Ashraf H, Qadeer MA, lqbal J (2005) Pearl millet, a source of alpha amylase production by Bacillus licheniformis. Bioresour Technol 96(10):1201-1204

Haq I, Ali S, Javed MM, Hameed U, Saleem A, Adnan F, Qadeer MA (2010) Production of alpha amylase from a randomly induced mutant strain of Bacillus amyloliquefaciens and its application as a desizer in textile industry. Pak J Bot 42(1):473-484

Harwood CR (1992) Bacillus subtilis and its relatives: Molecular, biological and industrial workhorses. Trends Biotechnol 10:247-256

Hillier P, Wase DAJ, Emery AN, Solomons GL (1997) Instability of a-amylase production and morphological variation in continuous culture of Bacillus amyloliquefaciens is associated with plasmid loss. Process Biochem 32:51-59
Huang H, Ridway D, Gu T, Moo-Young M (2003) A segregated model for heterologous a-amylase production by Bacillus subtilis. Enzyme Microb Technol 32:407-413

Kathiresan K, Manivannan S (2006) a-amylase production by Penicillium fellutanum isolated from mangrove rhizospheric soil. Afr J Biotechnol 5 (10):829-832

Kaur P, Vyas A (2012) Characterization and optimal production of alkaline a-amylase from Bacillus sp. DLB 9. Afr J Microbiol Res 6(11):2674-2681

Kumar CG, Takagi H (1999) Microbial alkaline protease: from a bioindustrial viewpoint. Biotechnol Adv 17(7):561-594

Kundu AK, Das S, Gupta TK (1973) Influence of culture and nurtitional conditions on the production of amylase by the submerged culture of Aspergillus oryzae. J Ferment Technol 51:142-150

Lin LL, Hsu WH (1997) A gene encoding for an alpha-amylase from thermophilic Bacillus sp. strain TS-23 and its expression in Escherichia coli. J Appl Microbiol 82:325-334

Lin LL, Tsau MR, Chu WS (1994) General characteristics of thermostable pullulanases and amylases from an alkalophilic Bacillus sp. TS-23. Appl Microbiol Biotechnol 42:51-56

Lin LL, Chyau CC, Hsu WH (1998) Production and properties of a raw-starch -degrading amylase from thermophilic and alkaliphilic Bacillus sp. TS-23. Biotechnol Appl Biochem 28:61-68

Lowry OH, Rosbrough NJ, Farr AL, Randall RJ (1951) Protein measurement with the Folin phenol reagent. J Biol Chem 193(1):265-275

Magee RJ, Kosaric N (1987) The microbial production of 2,3-butanediol. Adv Appl Microbiol 32:89-161

Mahmood S, Rahman SR (2008) Production and partial characterization of extracellular a-amylase by Trichoderma viride. Bangladesh J Microbiol 25 (2):99-103

Mendu DR, Ratnam BW, Purnima A, Ayyanna C (2005) Affinity chromatography of a-amylase from Bacillus licheniformis. Enzyme Microb Technol 37:712-717

Mielenz JR (1983) Bacillus stearothermophilus contains a plasmid-borne gene for alpha-amylase. Proc Natl Acad Sci 80:5975-5979

Miller GL (1959) Use of dinitrosalisylic acid reagent for determination of reducing sugar. Anal Chem 31(3):426-428

Mishra S, Behera N (2008) Amylase activity of starch degrading bacteria is isolated from soil receiving kitchen wastes. Afr J Biotechnol 7:3326-3331

Mishra S, Noronha SB, Kumar GKS (2005) Increase in enzyme productivity by induced oxidative stress in Bacillus subtilis cultures and analysis of its mechanism using microarray data. Process Biochem 40:1863-1870

Narang S, Satyanarayana T (2001) Thermostable alpha-amylase production by an extreme thermophilic Bacillus thermooleovorans. Lett Appl Microbiol 32(1):31-35

Nusrat A, Rahman SR (2007) Comparative studies on the production of extracellular a-amylase by three mesophilic Bacillus isolates. Bangladesh J Microbiol 24(2):129-132

Okalo BN, Ezeogu LI, Ebisike CO (1996) Raw starch digesting amylase from Thermoactinomyces thalophilus F13. World J Microb Biotechnol 12:637-638

Pandey A, Nigam P, Soccol CR, Soccol VT, Singh D, Mohan R (2000) Advances in microbial amylases. Biotechnol Appl Biochem 31:135-152

Prakash B, Vidyasagar M, Madhukumar MS, Muralikrishna G, Sreeramulu K (2009) Production, purification and characterization of two extremely halotolerant, thermostable, and alkali-stable a-amylases from Chromohalobacter sp. TVSP 101. Process Biochem 44:210-215

Rajagopalan G, Krishnan C (2008) Alpha-amylase production from catabolite derepressed Bacillus subtilis KCC103 utilizing sugarcane bagasse hydrolysate. Bioresour Technol 99(8):3044-3050

Riaz N, Haq IU, Qadeer MA (2003) Characterization of a-amylase by Bacillus subtilis. Int J Agr Biol 5(3):249-252

Schallmey M, Singh A, Ward OP (2004) Developments in the use of Bacillus species for industrial production. Can J Microbiol 50:1-17

Sexana R, Dutt K, Agarwal L, Nayyar P (2007) A highly thermostable and alkaline amylase from a Bacillus sp. PN5. Bioresour Technol 98(2):260-265

Sharma N, Vamil R, Ahmad S, Agarwal R (2012) Effect of different carbon and nitrogen sources on a-amylase production from Bacillius amyloliquefaciens. Int J Pharm Sci Res 3(4):1161-1163

Sumrin A, Ahmad W, ljaz B, Sarwar MT, Gull S, Kausar H, Shahid I, Jahan S, Asad S, Hussain M, Riazuddin S (2011) Purification and medium optimization of a-amylase from Bacillus subtilis 168. Afr J Biotechnol 10(11):2119-2129

Swain MR, Kar S, Padmaja G, Ray RC (2006) Partial characterization and optimization of production of extracellular a-amylase from Bacillus subtilis isolated from culturable cow dung microflora. Pol J Microbiol 55(4):289-296 
Swamy MV, Seenayya G (1996) Thermostable pullulanase and a-amylase activity from Clostridium thermosulfurogenes SV9-optimization of culture conditions for enzyme production. Process Biochem 31:157-162

Syu MJ, Chen YH (1997) A study on the a-amylase fermentation performed by Bacillus amyloliquefaciens. Chem Eng J 65:237-247

Tonkova A (1991) Effect of glucose and citrate on a-amylase production in Bacillus licheniformis. J Basic Microbiol 31:217-222

Wanderley KJ, Torres FAG, Moraes LMP, Ulhoa CJ (2004) Biochemical characterization of a-amylase from the yeast Cryptococcus flavus. FEMS Microbiol Lett 231(2):165-169

Wolfgang A (2007) Enzyme in industry: Production and Applications. Wiley-VCH, Weinheim

doi:10.1186/2193-1801-2-154

Cite this article as: Deb et al:: Production and partial characterization of extracellular amylase enzyme from Bacillus amyloliquefaciens P-001.

SpringerPlus 2013 2:154.

Submit your manuscript to a SpringerOpen ${ }^{\circ}$ journal and benefit from:

- Convenient online submission

- Rigorous peer review

- Immediate publication on acceptance

- Open access: articles freely available online

- High visibility within the field

- Retaining the copyright to your article

Submit your next manuscript at $>$ springeropen.com 